\title{
Examining the Push-Pull Motivations and Revisit Intention to Langkawi Island as Cultural Heritage Destination
}

\author{
Nor Asmalina Mohd Anuar ${ }^{1 *}$, Khairul Mohd Azemi ${ }^{2}$, Nurul Fadhlina Mohammad \\ Husni $^{3}$, Muhammad Firdaus Asraf Khalit ${ }^{4}$, Muhammad Amirul Izham Mohd \\ Nawawi ${ }^{5}$
}

${ }^{1}$ Universiti Teknologi MARA, Selangor Campus

${ }^{2}$ Politeknik Hulu Terengganu, Terengganu

${ }^{3}$ Universiti Teknologi MARA, Selangor Campus

${ }^{4}$ Universiti Teknologi MARA, Selangor Campus

${ }^{5}$ Universiti Teknologi MARA, Selangor Campus

*Corresponding author.Email: noras288@uitm.edu.my

\begin{abstract}
Langkawi Island is one of the popular tourism destinations in Malaysia that presents a diverse range of activities and offerings. In fact, this area has valued the cultural heritage experience and authentically symbolizes the stories and people of the past and present, which include historical, cultural and other heritage attractions. In planning to visit a destination, there are always push and pull motivations which have influenced the tourists' choices. Looking at various integrated factors, this paper aimed to understand travel motivations of tourists and to examine on how pushpull motivations on the intention to revisit Langkawi Island. Besides, it also to investigate the significant relationship and direct affects between both motivation attributions and the intention behaviour. Data was collected from 150 respondents who had visited Langkawi Island. This study discovered a few key determinants on push and pull that motivated the tourists revisit behaviours in cultural heritage attraction. In terms of relationship, the push and pull motivations have positive influence and direct affect towards the tourist's revisit intention. Implications were discussed concerning Langkawi Island as cultural heritage attraction that needs to be highlighted in terms of enhancement and plan from various stakeholders' perspectives. This study has significantly provided practical indication on the essential roles of push and pull motivations. Besides, it can also help as a general idea to propose constructive recommendations to the relevant stakeholders in developing tourism strategies and plans, predominantly in cultural and heritage tourism settings. Later, it can enhance the level of participation of tourists and encourage them in returning to the area.
\end{abstract}

Keywords: Cultural Heritage, Push Motivation, Pull Motivation, Revisit Intention

\section{INTRODUCTION}

Tourism researchers have long documented the importance of reviewing factors on what motivate tourists to travel and toward tourism destinations. This is to better foresee the travel decisions and tourists' consumption behaviours. The well-known theory of the 'push-pull factor' by Tolman [1] and subsequent by Dann [2], is feasibly the most established theory within the field of tourism research. An enhanced understanding of travel motivations would help out in segmenting the markets, thereby letting tourism marketers to distribute scarce tourism resources more efficiently [3].

Alluring tourists either first-time tourists or return tourists is the most significant part in supporting economic expansion through the tourism industry in a state or country [4]. According to the existing studies, tourists' experiences and their satisfaction with a destination are main contributing factors of their intention to revisit the destination [5]. Despite the improvement made in the understanding on influences 
of tourists' experiences and satisfaction, there is still a need for a better grasp on the aspects of tourist behaviour that determine revisit intention. Valuing empirical literature, many studies tend to discover physical conditions such as tourist attractions, tourism activities and programs, amenities, facilities, services, resources and transportation accessibility as the determinants of tourists' intention to revisit.

\subsection{Background of the study}

Cultural and heritage tourism is a tool of economic development that achieves economic growth through attracting visitors from outside a host community, who are motivated wholly or in part by interest in the historical, artistic, scientific or lifestyle/heritage offerings of a community, region, group or institution [6]. Such travel is focused upon experiencing cultural environments, including landscapes, special lifestyles, values, traditions, events, and the visual and performing arts.

Langkawi Island, that is located in the northern part of Peninsula Malaysia and known as the 'Jewel of Kedah' has a lot of things to be offered to the domestic and international tourists. It is also known for its numerous histories, cultures, natures and amazing geography. In fact, Langkawi Island received a recognition as UNESCO World Geopark for its nature and conservation. Tourists visit Langkawi Island for many reasons and motivations, and it comprised of both leisure and business purposes [7]. Tourists also seek escapism from the hustle-bustle of life, to find relaxation in Langkawi Island. However, some reviews from literature stated that very limited number of recent studies have focused on Langkawi Island as cultural tourism destination. Indeed, less studies are conducted on the motivational factors that influence the revisitation behaviour to the area and the level of competitiveness in this field also considerably weak. Therefore, these would be recommended as future research and the extend of information $[8,9,10]$.

According to Childs [11], cultural tourists typically visit cultural heritage attractions such as heritage landmarks; archaeological sites; state, local, or national parks; art galleries or museums; concerts, performances or musicals; cultural sites or ecological heritage; and other tourist spots related to cultural and heritage activities. Visiting Langkawi Island would be such a wonderful time for the cultural tourists from various regions and countries. In Malaysian context, as mentioned by Ghouse Nasuruddin [12], traditional tangible cultural heritage is being ignored because of lack of awareness of its value and its national identity and pride. Perhaps, in Langkawi Island some cultural heritage products, sites and activities was well-known among the tourists many years ago, but now slowly had been forgotten or not in their priority list. In this situation, the ignorance of the traditional cultural heritage or lack of awareness can also be related to the generation of tourists. According to Kesterson [13], it is assumed that the Millennial or younger generation may have different preferences, awareness, participation and concern on cultural heritage tourism from previous generation.

Based on the statement by LADA Chief Executive Officer, cultural heritage products should be focused on Langkawi Island. Despite of the richness of its diversity, there is still some parts that are lacking and need more supports, especially in socio-cultural sector. As one of the initiatives, on the official website Langkawi Development Authority [14] they make an event which depicted a positive collaboration with "Langkawi Tour Guide Association" (LTGA). This event was about "Kuah Down the Memory Lane Walk", with objective of promoting the culture and heritage at Kuah town. The purpose of this event by LADA was to promote cultural tourism products and to attract tourists to visit Langkawi Island. Despite the importance of the cultural attractions in Langkawi Island, very little is known about the motivational factors that influence the revisitation behaviour to the area. This research attempted to fill this void by having a few objectives. More specifically, the objectives were to: (1) to investigate the push-pull motivations of tourists to Langkawi Island as cultural heritage destination; (2) to examine the relationship of push-pull motivations and revisit intention to Langkawi Island as cultural heritage destination.

\section{LITERATURE REVIEW}

\subsection{Tourist Motivation}

Tourist motivation plays a critical role in where the choices are being counted and made especially travel or trip planning. There are always various reasons why tourists choose to visit a destination as well as to revisit. By classifying and integrating the reasons, this would allow tourism agents or any stakeholders to attract more tourists, attracting them to stay longer, increasing their enjoyment, changing anti-social actions, and much more [15].

According to Hamid Tohidi [16], tourist motivation is defined as "powering tourists to achieve high levels of actions and overcoming obstacles or changes". As mentioned above, the motivation generally means to persuade people to change in order to attain the goal. Additionally, motivation is the driver of guidance, control and persistence in human behaviour [16]. Motivation is energy that drive human activities and decision, and it has connection with the travel motivation concept of Maslow (17), which has been categorised into different level and combined with various dimensions of social, psychological, economic, situational, and environmental changes [18]. 


\subsubsection{Push and Pull Motivations}

In tourism research, the push and pull context present a useful approach for examining the motivations underlying tourist and revisit behaviour $[2 ; 19 ; 20]$. Push motivation is regarded as the personal driver which entice an individual to travel under one's reasons such as escape from the day-to-day schedule, a need to fill valuable time with the family, or the desire for adventure [2]. Pull motivation is the reason that fascinates tourists to decide on the destination site. Niemelä [21] pointed out that a tourist's view of a particular destination can be perceived as pull motivation.

In this basis, push factors refer to the specific influences that have an effect on a person's decision to take a vacation (i.e., to travel outside of one's normal environment), while pull factors indicate to the influences that change the person's decision of which specific destination should be selected [20]. The push motivations have been considered useful in explaining the desire for travel and indicated as to be sociopsychological motivations that predispose the individual to travel $[22 ; 23]$. On contrary, the pull motivations refer to the actual destination choice that attracting the individual to a specific destination once the decision has been made $[23 ; 24]$.

Klenosky [20] elaborated that push factors have related to the needs and wants of the tourists, such as the wish for escape, rest and relaxation, exploration, prestige, wellbeing and fitness, and social interaction. Pull factors, in contrast, have been described in terms of the characteristics, attractions, or determinants of the destination itself, for instances sunshine, beaches, leisure facilities, and low-cost airfares.

\subsubsection{Push and Pull Motivations in Cultural Heritage Tourism}

Different types of tourism such as natural or cultural destination have distinct pull influences $[25 ; 26)$. There are previous studies pointed to influences of attractiveness of cultural heritage $[27 ; 28 ; 29]$. Cultural heritage tourism motivation has a substantial impact on visitor commitment, experience, and heritage destination position [30].

$\mathrm{Li}$ and Lo [28] discovered the tourism potential of cultural heritage positions through various aspects, including environment, status of the area, prominent symbols, interesting surrounding events, regional tourism activity, cultural destination, amenity, accessibility, heritage type, and many more. McKercher et al. [27] indicated that the attributes of popular cultural tourism attractions are product, experiential, uniqueness, marketing, culture, and leadership.
In the push motivations of cultural heritage tourism, Li and Lo [28] evaluated numerous principles in cultural heritage and implied that some cases include aesthetic, historical, learning, social, or scientific benefit. Barton et al. [31] specified that the key motivating factors also include strolling at natural heritage sites while appreciating clean air, enjoying the scenery, observing wildlife, valuing exercises, understanding heritage value, meeting family and friends, having recreation and such. Tu [32] also captured four pushed essential motivations, including self-growth (knowledge, growth, rethinking, work inspiration, and accomplishments), health benefits (constructive emotions, decent life, and health care), social benefits (healthy relations and memoirs), and cultural benefits (cultural legacy and a sense of belonging). Generally, the push motivations of cultural heritage tourism consisted of several push factors of general tourism, except cultural benefits.

$\mathrm{Tu}$ [32] apprehended the push-pull motivations of cultural heritage tourism with popular adaptive cases in Taiwan through interviews with tourists, and emphasized four pull factors, comprising heritage reuse environments (architecture, cultural atmosphere, style, well-preserved heritage, history and culture, and heritage beautification), activities of reuse environments (food service, motionless art activities, walking, family activities, and lively art programs), natural environments (leisure, natural, and spacious landscape, a well-maintained and harmless atmosphere), and regional environments (nearby tourist attractions, convenience to transportation, and historical avenue).

For the pull motivations, Bonn et al. [33] revealed that the attributions covered heritage position, cultural value, history, ambience, and design encompass, whereas Calver and Page [34] indicated that the overall attributes anticipated with the levels of pleasure and behavior in cultural and heritage tourism. In other condition, some environmental influences have no significant effect on visitors' evaluation, such as expanding the number of replicas, the existence of a gallery, audiovisual impact, and traveling showcases [35].

\subsection{Relationship between push and pull motivations}

Push and pull factors have commonly been described as relating to two distinct decisions made at two different goals in time - one focusing on whether to go and the other is on where to go. Rationally, the push factors precede the pull factors $[2,36 ; 20]$.

In contrast to this viewpoint, other researchers have indicated that push and pull factors should not be perceived as being entirely independent of each other but rather as being profoundly related to each other [20]. In regard, it has been observed that while the 
internal forces push people to travel, the external forces of the destination itself at once pull them to select that particular destination $[37 ; 24]$.

Dann [36] has pointed out that potential tourists who decided "where to go" may also take into consideration numerous pull factors which correspond sufficiently to their motivational of 'push'. Although a few research have examined the interrelationship between push and pull forces in the travel and tourism literature $[38 ; 20$; 39 ; 40; 24], most prior studies have focused primarily on visitors to international and overseas tourism destinations. Researchers are yet to investigate more on the relationship between push and pull factors in various settings or socio-demographic variables.

\subsection{Revisit Intention}

The notion of revisit intention comes from behavioral intention, which is described as "an anticipated or planned behavior in the future" [41]. In the previous studies, this planned behavior theory is the most proximate dimension and effective instrument to identify social behavior [42; 43]. Khuong and Ha [44] indicated that "revisit intention is the tourist's decision about the likeliness to re-visit a destination or attraction". In fact, the tourists' intention to return to the same destination especially in foreign land considerably much lower even if this destination has fulfilled the tourists' needs and expectations, and this is due to the inclination to select other places that they have not yet visited for new other experiences [45]. However, the situation possibly be shifted or changed if there are some improvements or added values, which conceivably attract the tourists to return after quite some time. Return intention or recommend intention is a major constituent of destination loyalty [44]. Hence, tourist destination authorities need to consider the intention to re-visit among the tourists as one of the underlying issues [46]. It is because the return tourists constantly help in generating source of income and revenue for the destination and its whole operation [47].

\section{METHODOLOGY}

\subsection{Study site and data collection}

The data used in this study were collected from 150 tourists or respondents who visited Langkawi Island. The sample size is a significant feature of any empirical study in which the goal is to make inferences about a population from a sample [48]. The sample size of 150 is enough with the variables of study to prevent any attrition that may occur during collecting this data. The calculation used on the sample size was referred to the formula of Tabachnick and Fidell [49]. In this study, closed-ended questionnaires were contemplated with adapted items and review of the tourism literatures on motivation, awareness, and revisit intention. Out of 178 distributions, 150 are useable and selected to be analysed.

The questions were divided into four sections; Section A is on demographic profile of respondents which related to gender, marital status, age group, education level, occupation and income level; whereas in Section B on push motivation (7 items), section C on pull motivation (7 items) and lastly in Section D on revisit intention (4 items).

All items were measured on a 5-point Likert scale. Respondents were asked to indicate their level of agreement toward each statement, from strongly disagree (1) to strongly agree (5). All of questions were tested to ensure the reliability and validity of the constructs. In this study, the data analysis procedures also included Pearson correlation, where the correlation analysis is an analysis process used to examine the relationship among the variables and to know how positive the relationship is. In this study, independent variables are push motivation and pull motivation, and the dependent variable is intention to revisit. There are two hypotheses developed for this study including H1: Push motivation is positively and directly affect tourist's revisit intention and $\mathrm{H} 2$ : Pull motivation is positively and directly affect tourist's revisit intention.

\section{RESULTS}

\subsection{Descriptive Analysis}

In Table 1, it explains the information about the characteristics of the respondents. The demographic profile of the respondents showed that the gender of the respondents was not equally distributed, with 92 female respondents $(61.3 \%)$ and 58 male respondents $(38.7 \%)$. More than half of the respondents' marital status was single $(57.7 \%)$ and other $42.3 \%$ indicated married. The age group was divided into three categories which between 18 to 25 years old (34.0\%), 26 to 35 years old $(32.0 \%), 36$ to 45 years old $(21.3 \%)$ and above 45 years old $(12.7 \%)$. Concerning the education level, $57.3 \%$ of the respondents held diploma/bachelor's degree, followed by high school or lower $(27.3 \%)$, master's degree $(10.7 \%)$, and doctoral degree $(4.7 \%)$. The largest demographic group was from category of students $(31.3 \%)$, followed by government servant (26.7\%), private sector $(21.3 \%)$, self-employed (10.7\%) housewife/unemployed $(7.3 \%)$, and others $(2.7 \%)$. As for the income, highest percentage respondents had an income of between RM3,001-RM5,000 per month (32.0\%), followed by $26.0 \%$ of RM3,000 and less per month, $23.3 \%$ respondents had an income between RM5,001-RM10,000 per month and only $18.7 \%$ of respondents have income above RM10,000 per month. 
Table 1. Demographic profile

\begin{tabular}{|l|c|c|}
\hline Classification & Frequency & Percentage (\%) \\
\hline Gender & 92 & 61.3 \\
\hline Female & 58 & 38.7 \\
\hline Male & & \\
\hline Marital Status & 86 & 57.3 \\
\hline Single & 64 & 42.7 \\
\hline Married & 51 & 34.0 \\
\hline Age group & 48 & 32.0 \\
\hline $18-25$ years old & 32 & 21.3 \\
\hline $26-35$ years old & 19 & 12.7 \\
\hline $36-45$ years old & & \\
\hline Above 45 years old & 41 & 27.3 \\
\hline Education level & 86 & 57.3 \\
\hline High school or lower & 16 & 10.7 \\
\hline Diploma/Bachelor's degree & 7 & 4.7 \\
\hline Master's degree & & \\
\hline Doctoral degree & 47 & 31.3 \\
\hline Occupation & 40 & 26.7 \\
\hline Students & 32 & 21.3 \\
\hline Government servant & 16 & 10.7 \\
\hline Private sector & 11 & 7.3 \\
\hline Self-employed & 4 & 2.7 \\
\hline Housewife/unemployed & & \\
\hline Others & 39 & 26.0 \\
\hline Income level (per month) & 48 & 32.0 \\
\hline Less than RM3,000 & 35 & 23.3 \\
\hline RM3,001 - RM5,000 & 28 & 18.7 \\
\hline RM5,001 - RM10,000 & & \\
\hline More than RM10,000 & & \\
\hline & & \\
\hline & & \\
\hline
\end{tabular}

\subsection{Measurement results of relevant variables}

Table 2 illustrates the descriptive statistics which related to mean values and standard deviations on push motivations attributes. In this study, the tourists responded that "Cultural heritage generates precious histories and nostalgia" is the most important push motivation which was reflected by the highest mean score of 4.206. The lowest mean score is "Cultural heritage improves mood and good life (3.863).

Table 2. Descriptive Analysis of Variables

\begin{tabular}{|l|c|c|c|}
\hline $\begin{array}{l}\text { Push motivations } \\
\text { attributes }\end{array}$ & Rank & Mean & Std. Dev \\
\hline $\begin{array}{l}\text { Cultural heritage } \\
\text { encourages self-growth }\end{array}$ & 6 & 3.995 & 0.783 \\
\hline $\begin{array}{l}\text { Cultural heritage offers } \\
\text { fun and leaning } \\
\text { experiences }\end{array}$ & 2 & 4.185 & 0.839 \\
\hline $\begin{array}{l}\text { Cultural heritage identifies } \\
\text { culture inheritance }\end{array}$ & 4 & 4.020 & 0.794 \\
\hline $\begin{array}{l}\text { Cultural heritage } \\
\text { generates precious } \\
\text { histories and nostalgia }\end{array}$ & 1 & 4.206 & 0.775 \\
\hline $\begin{array}{l}\text { Cultural heritage } \\
\text { promotes interaction with } \\
\text { family and friends }\end{array}$ & 5 & 4.005 & 0.791 \\
\hline $\begin{array}{l}\text { Cultural heritage provides } \\
\text { sense of knowledge } \\
\text { achievement }\end{array}$ & 3 & 4.183 & 0.793 \\
\hline $\begin{array}{l}\text { Cultural heritage } \\
\text { improves mood and good } \\
\text { life }\end{array}$ & 7 & 3.863 & 0.917 \\
\hline
\end{tabular}

For pull motivations attributes as illustrated in Table 3 , the tourists responded that "Cultural heritage's architecture and history" is the most important determinant with the highest mean score of 4.321 and the least important with the lowest mean score of 3.967 is "Cultural heritage's surrounding attractions".

Table 3. Descriptive Analysis of Variables

\begin{tabular}{|l|c|c|c|}
\hline $\begin{array}{l}\text { Pull motivations } \\
\text { attributes }\end{array}$ & Rank & Mean & Std. Dev \\
\hline $\begin{array}{l}\text { Cultural heritage's } \\
\text { outdoor landscape and } \\
\text { environment }\end{array}$ & 3 & 4.195 & 0.796 \\
\hline $\begin{array}{l}\text { Cultural heritage's } \\
\text { surrounding attractions }\end{array}$ & 7 & 3.967 & 0.801 \\
\hline $\begin{array}{l}\text { Cultural heritage's } \\
\text { architecture and history }\end{array}$ & 1 & 4.321 & 0.793 \\
\hline $\begin{array}{l}\text { Cultural heritage's art and } \\
\text { traditional } \\
\text { activities/events }\end{array}$ & 2 & 4.203 & 0.773 \\
\hline $\begin{array}{l}\text { Cultural heritage's safety } \\
\text { environment }\end{array}$ & 5 & 4.021 & 0.803 \\
\hline $\begin{array}{l}\text { Cultural heritage's food } \\
\text { Cultural heritage's } \\
\text { convenience sites and } \\
\text { accessibility }\end{array}$ & 4 & 4.059 & 0.689 \\
\hline
\end{tabular}

For the last variable intention to revisit as illustrated in Table 4, "I would like to explore more trips on cultural and heritage sites in Langkawi Island" has the highest mean score of 4.393 and "I would tell positive things about cultural heritage tourism in Langkawi Island to friends and relatives" has the lowest mean of 3.873 .

Table 4. Descriptive Analysis of Variables

\begin{tabular}{|l|c|c|c|}
\hline $\begin{array}{l}\text { Intention to revisit } \\
\text { attributes }\end{array}$ & Rank & Mean & Std. Dev \\
\hline $\begin{array}{l}\text { I would tell positive things } \\
\text { about cultural heritage in } \\
\text { Langkawi Island to friends } \\
\text { and relatives }\end{array}$ & 4 & 3.873 & 0.903 \\
\hline $\begin{array}{l}\text { I would recommend } \\
\text { friends and relatives to } \\
\text { travel to Langkawi Island }\end{array}$ & 2 & 4.206 & 0.694 \\
\hline $\begin{array}{l}\text { I would like to explore } \\
\text { more trips on cultural and } \\
\text { heritage sites in Langkawi } \\
\text { Island }\end{array}$ & 1 & 4.393 & 0.810 \\
\hline $\begin{array}{l}\text { I would like to revisit } \\
\text { Langkawi Island more } \\
\text { often in the future }\end{array}$ & 3 & 4.186 & 0.782 \\
\hline
\end{tabular}

\subsection{Result of Pearson's Correlation Analysis}

For hypothesis testing, the results of Table 5 revealed that there was a strongly positive relationship between the dependent variable of intention to revisit and both the independent variables that include push motivation $(\mathrm{r}=0.662, \mathrm{p}<0.01)$ and pull motivation $(\mathrm{r}=0.472, \mathrm{p}<$ 0.01 ). 
Table 5. Result of Pearson's Correlation Analysis

\begin{tabular}{|l|l|l|l|l|}
\hline \multicolumn{5}{|l|}{ Pearson's Correlation Analysis } \\
\hline \multirow{2}{*}{ Push } & Push & Pull & $\begin{array}{l}\text { Revisit } \\
\text { Intention }\end{array}$ \\
\hline & Pearson correlation & 1 & $0.653^{* *}$ & $0.662^{* *}$ \\
\cline { 3 - 5 } & Sig. (2-tailed) & & 0.000 & 0.000 \\
\cline { 3 - 5 } & $N$ & 150 & 150 & 150 \\
\hline Pull & Pearson correlation & $0.653^{* *}$ & 1 & $0.472^{* *}$ \\
\cline { 3 - 5 } & Sig. (2-tailed) & 0.000 & & 0.000 \\
\cline { 3 - 5 } & $N$ & 150 & 150 & 150 \\
\hline Revisit & Pearson correlation & $0.662^{* *}$ & $0.472^{* *}$ & 1 \\
\cline { 3 - 5 } Intention & Sig. (2-tailed) & 0.000 & 0.000 & \\
\cline { 3 - 5 } & $N$ & 150 & 150 & 150 \\
\hline & $N$ & Note. **: Correlation is significant at the 0.01 level (2-tailed)
\end{tabular}

$\mathrm{H} 1$ foresees that push motivation is posited to positively and directly affect tourist's intention to revisit Langkawi Island as cultural heritage destination. Push motivation has a positive impact on intention to revisit $(\beta=0.662, p$ $<0.001)$. Therefore, H1 is supported.

$\mathrm{H} 2$ foresees that pull motivation is posited to positively and directly affect tourist's intention to revisit Langkawi Island as cultural heritage destination. Pull motivation has a positive impact on intention to revisit $(\beta=0.472, p$ $<0.001)$. Therefore, $\mathrm{H} 2$ is supported. Based on the analysis discussed, the results of hypotheses testing are summarized in Table 6.

Table 6. Hypotheses and Results of Empirical Test

\begin{tabular}{|c|l|c|}
\hline$H(x)$ & \multicolumn{1}{|c|}{ Research Hypothesis } & Results \\
\hline $\mathrm{H} 1$ & $\begin{array}{l}\text { Push motivation is positively and directly } \\
\text { affect tourist's revisit intention to Langkawi } \\
\text { as cultural heritage destination }\end{array}$ & Supported \\
\hline $\mathrm{H} 2$ & $\begin{array}{l}\text { Pull motivation is positively and directly } \\
\text { affect tourist's revisit intention to Langkawi } \\
\text { as cultural heritage destination }\end{array}$ & Supported \\
\hline
\end{tabular}

\section{IMPLICATION, CONCLUSION AND LIMITATION}

Tourists can be influenced by the push and pull motivations to visit or revisit the destination. From this study, the push attributes that focuses on bringing precious histories, nostalgic, learning experiences, knowledge and culture inheritance motivate the cultural tourists to return to the area. Meanwhile, the pull attributes like architecture, traditional arts, landscape, environment as well as food and services which provide connection to the cultural heritage identity also influence the tourists to revisit and participate more in the future.

There are many cultural and heritage tourism sites that need to be highlighted for the tourism planning in Langkawi Island. The stakeholders must create something appealing to the tourists such as heritage festivals that cover the local and traditional food to the arts and handicraft. Continuous and initiative-taking promotion on cultural heritage should also be in line together with other Langkawi Island's products and activities such as nature, and adventure. Zuliskandar [50] supported that this field of cultural and heritage tourism is not something new, but then the promotion for this area is still lacking. The attractions on the culture heritage tourism in Langkawi need to be more highlighted especially to the stakeholders that comprised of authorities, entrepreneurs, marketers, associations and many more. Travel businesses may take the opportunity to enhance and produce interesting cultural tour packages for inbound and domestic markets. With numerous ways of promotion and awareness through social media can also be one of the methods to encourage the intention behaviour.

For the limitation, this study used only online platform as the medium to get respondents. This limited approach was due to Pandemic Covid-19 that restricted the tourists to travel and move. Future study may extend the current study and examine any mediating or moderating variables. Since this study focused only on the tourists who have visited Langkawi Island, it can also be expanded in the future by looking at various stakeholders' perspectives. Besides, comparison studies can also be conducted in diverse cultural heritage destinations or attractions.

\section{REFERENCES}

[1] E.C. Tolman, Principles of purposive behaviour. In S. Koch (Ed.), Psychology: A Study of a Science. 1959, 2, pp. 92-157. New York: McGraw-Hill

[2] G.M.S. Dann, Anomie, ego-enhancement and tourism. Annals of Tourism Research. 1977, 4(4), pp. 184-194.

[3] M. Uysal, X. Li, E. Sirakaya-Turk, Push-pull dynamics in travel decisions. In O. Haemoon (Ed.), Handbook of Hospitality Marketing Management. 2008, pp. 412-439. Butterworth-Heinemann: Oxford. DOI: https://doi.org/10.1016/B978-0-08045080-3.50018-4E.M

[4] W. Kim, Determinants of Tourists' Revisit Intention in Domestic Tourism. International Journal of Advanced Culture Technology. 2021, 9(3), pp. 74-80. DOI: https://doi.org/10.17703/IJACT.2021.9.3.74.

[5] H. Choo, J.F. Petrick, Social interactions and intentions to revisit for agritourism service encounters. Tourism Management. 2014, 40, pp. 372-381.

[6] T. Silberberg, Cultural tourism and business opportunities for museums and heritage sites. Tourism Management. 1995, 16(5), pp. 361-365.

[7] K.A. Mansor, W.I. Ishak, Forecasting tourist arrivals to Langkawi Island Malaysia, Cross 
Cultural Management Journal, Fundaţia Română pentru Inteligența Afacerii, Editorial Department. 2015, 1, pp. 69-76,

[8] N.K. Aliman, S.M. Hashim, S.D.M. Wahid, S. Harudin, Tourists' Satisfaction with a Destination: An Investigation on Visitors to Langkawi Island, International Journal of Marketing Studies, 2016, 8(3), pp. 173-188.

[9] N. Mohd Shariff, A. Zainol Abidin, Tourists' perceptions of Langkawi Island as a world tourism destination, GeoJournal of Tourism and Geosites. 2020, 32(4), pp. 1264-1269. DOI: https://doi.org/10.30892/gtg.32411-567.

[10] Z. Zainuddin, S.M. Radzi, M.S.S. Zahari, Perceived Destination Competitiveness of Langkawi Island, Malaysia. Procedia - Social and Behavioural Sciences. 2016, pp. 390-397. DOI: https://doi.org/10.1016/j.sbspro.2016.05.190

[11] C. Childs, 'How Culture and Heritage Tourism Boosts More Than a Visitor Economy'. MyTravelResearch.com. DOI: https://www.mytravelresearch.com/culture-andheritage-tourism-boosts-visitor-economy/ April, 2015.

[12] M.G. Nasuruddin, 'Preserve cultural authenticity'. News Straits Times. 2017, July 2017, DOI: https://www.nst.com.my/opinion/columnists/2017/ 07/254092/preserve-cultural-authenticity

[13] K.D. Kesterson, The Relationships between 'Push' and 'Pull' Factors of Millennial Generation Tourists to Heritage Tourism Destinations: Antebellum and Civil War Sites in the State of Arkansas. 2013, Theses and Dissertations. 983. http://scholarworks.uark.edu/etd/983

[14] Langkawi Development Authority. LADA adopted different approach to promote cultural tourism. 2020 , DOI: https://www.tin.media/news/details/ladahasadopted -diferrent-approache-to-promote-cultural-tourism-

[15] K. Dewar, D. Meyer, W. Li, Harbin, Lanterns of ice, sculptures of snow. Tourism Management. 2001, 22(5), pp. 523-532.

[16] Hamid Tohidi, Mohammad Mehdi Jabbari, The effect of motivation in education. 2012, DOI: https://www.sciencedirect.com/science/article/pii/S 1877042811030771.

[17] A.H. Maslow, Motivation and Personality. 1954, New York, NY: Harper \& Row.

[18] J. Park, M. Kim, J. Nauright, Y. Kim, Sport event touristse $^{\text {ee }}\left(\mathrm{SET}^{\mathrm{ee}} \mathrm{s}\right)$ behaviour: A case study of the
PyeongChang Winter Olympics. International Journal of Sports Marketing and Sponsorship. 2019, 21(2), pp. 267-284. DOI: https://doi.org/10.1108/IJSMS-09-2019-0101

[19] Z.Q. Hanqin, T. Lam, Analysis of Mainland Chinese visitors' motivations to visit Hong Kong. Tourism Management.1999, 20, pp. 587-594.

[20] D.B. Klenosky, The "Pull" of Tourism Destinations: A Means-End Investigation. Journal of Travel Research. 2002, 40, pp. 385-395.

[21] Niemelä, Titta. Motivation Factors in Dark Tourism, Case: House of Terror, Lahti University of Applied Science, The Faculty of Tourism and Hospitality Degree Programme in Tourism and Hospitality Management Nature and Soft Adventure Tourism Bachelor's thesis. 2010.

[22] J. Crompton, Motivations for pleasure vacations, Annals of Tourism Research. 1979, 6(4), pp. 408424.

[23] M. Uysal, L. Hagan, "Motivations for pleasure travel and tourism," Encyclopaedia of Hospitality and Tourism, New York: Van NostrandReinhold. 1993, pp. 798-810.

[24] M. Uysal, C. Jurowski, An empirical testing of the push and pull factors of tourist motivations, Annals of Tourism Research. 1993, 21(4), pp. 844-846.

[25] J. Swarbrooke, S.J. Page, Development and Management of Visitor Attractions. 2012, Butterworth-Heinemann: Oxford, UK.

[26] E. Inskeep, Tourism Planning: An Integrated and Sustainable Development Approach. 1991, Van Nostrand Reinhold: New York, NY, USA.

[27] B. McKercher, P.S. Ho, H. du Cros, Attributes of popular cultural attractions in Hong Kong. Annals of Tourism Research. 2004, 31, pp. 393-407.

[28] Y. Li, R.L.B. Lo, Applicability of the market appeal-Robusticity matrix: A case study of heritage tourism. Tourism Management. 2004, 25, pp. 789-800.

[29] M. Gravari-Barbas, Tourism as a heritage producing machine. Tourism Management Perspective. 2018, 25, pp. 173-176.

[30] D.N. Su, N.A.N. Nguyen, Q.N.T. Nguyen, T.P. Tran, The link between travel motivation and satisfaction towards a heritage destination: The role of visitor engagement, visitor experience and heritage destination image. Tourism Management Perspective. 2020, 34, 100634.

[31] J. Barton, R. Hine, J. Pretty, The health benefits of walking in greenspaces of high natural and heritage 
value. Journal of Integration Environment Science. 2009, 6, pp. 261-278.

[32] H.M. Tu, The attractiveness of adaptive heritage reuse: A theoretical framework. Sustainability. 2020, 12, 2372.

[33] M.A. Bonn, S.M. Joseph-Mathews, M. Dai, S. Hayes, J. Cave, Heritage/cultural attraction atmospherics: Creating the right environment for the heritage/cultural visitor. Journal of Travel Research. 2007, 45, pp. 345-354.

[34] S.J. Calver, S.J. Page, Enlightened hedonism: Exploring the relationship of service value, visitor knowledge and interest, to visitor enjoyment at heritage attractions. Tourism Management. 2013, 39 , pp. 23-36.

[35] M.M. Alazaizeh, J.C. Hallo, S.J. Backman, W.C. Norman, M.A. Vogel, Value orientations and heritage tourism management at Petra Archaeological Park, Jordan. Tourism Management. 2016, 57, pp. 149-158.

[36] G.M.S. Dann, G.M.S. (1981). Tourist Motivation: An Appraisal. Annals of Tourism Research, 8(2), pp. 187-219.

[37] S. Cha, K. McCleary, M. Uysal, Travel motivations of Japanese overseas travellers: A factor-cluster segmentation approach. Journal of Travel Research. 1995, 34(1), pp. 33-39.

[38] S. Baloglu, M. Uysal, Market segments of push and pull motivations: A canonical correlation approach. International Journal of Contemporary Hospitality Management. 1996, 8(3), 32-38.

[39] H.C. Oh, M. Uysal, P. A. Weaver, Product Bundles and Market Segments Based on Travel Motivations: A Canonical Correlation Approach. International Journal Hospitality Management. 1995, 14 (2), pp. 123-137. (1995).

[40] S. Pyo, B. J. Mihalik, M. Uysal, Attraction Attributes and Motivations: A Canonical Correlation Analysis. Annals of Tourism Research. 1989, 16 (2), pp. 277-282.

[41] M. Fishbein, I. Ajzen, Belief, Attitude, Intention and Behaviour: An Introduction to Theory and Research, Reading, Massachusetts: AddisonWesley, 1975, ch. 7.

[42] I. Ajzen, The theory of planned behaviour, Organizational Behaviour and Human Decision Processes, 50(2), pp. 179-211, 1991.

[43] M. Fishbein, M. Manfredo, A theory of behaviour change, in Influencing Human Behaviour: Theory and Applications in: Recreation, Tourism, and
Natural Resources Management, M. Manfredo, Ed. Champaign, IL: Sagamore Publishing. 1992, pp. 29-50.

[44] M.N. Khuong, H.T. Ha, The influences of push and pull factors on the international leisure tourists' return intention to Ho Chi Minh city, Vietnam: A mediation analysis of destination satisfaction. International Journal of Trade, Economics and Finance. 2014, 5(6), pp. 490-496. DOI: 10.7763/IJTEF.2014.V5.421.

[45] G. McDougall, H. Munro, Scaling and attitude measurement in travel and tourism, in: Travel Tourism and Hospitality Research, B. Ritchie and C. Goeldner, Eds. 2nd ed. New York: John Wiley \& Sons, Inc. 1994, pp. 115-129.

[46] S.A. Pratminingsih, C.L. Rudatin, T. Rimenta, Roles of motivation and destination image in predicting tourist revisit intention: A case of Bandung - Indonesia. International Journal of Innovation, Management and Technology. 2014, 5(1), pp. 19-24.

[47] J. T. Bowen, S. Chen, The relationship between customer loyalty and customer satisfaction, International Journal of Contemporary Hospitality Management. 2001, 13(5), pp. 213-217.

[48] Taherdoost, Hamed, Determining Sample Size; How to Calculate Survey Sample Size. International Journal of Economics and Management Systems. 2017, 2, DOI: https://ssrn.com/abstract=3224205.

[49] B.G. Tabachnick, L.S. Fidell, Using multivariate statistics (6th ed.). Boston: Pearson. 2013.

[50] Zuliskandar Ramli, Heritage Tourism in Malaysia: Potential and Challenges. The Social Sciences. 2017, 12, pp. 431-440. DOI: 10.36478/sscience. 2017.431 .440 